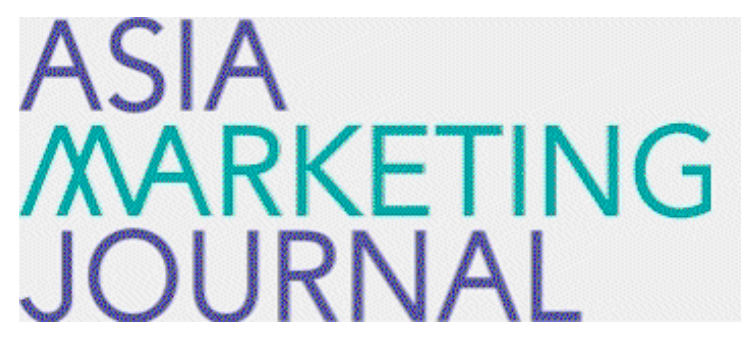

ASIA MARKETING JOURNAL

Volume 14 | Issue 4

Article 2

$1-30-2013$

\title{
WE CAN Cookies
}

Dae Ryun Chang

Kyong On Choi

Follow this and additional works at: https://amj.kma.re.kr/journal

Part of the Marketing Commons

\section{Recommended Citation}

Chang, Dae Ryun and Choi, Kyong On (2013) "WE CAN Cookies," Asia Marketing Journal: Vol. 14 : Iss. 4 , Article 2.

Available at: https://doi.org/10.53728/2765-6500.1498

This Article is brought to you for free and open access by Asia Marketing Journal. It has been accepted for inclusion in Asia Marketing Journal by an authorized editor of Asia Marketing Journal. 


\title{
WE CAN Cookies* \\ A Case Study in a Pioneering Social Enterprise in South Korea
}

\author{
Dae Ryun Chang** \\ Kyongon Choi ${ }^{* * *}$
}

This case focuses on WE CAN Cookies, a social enterprise in South Korea that was founded in 2001 with the support of the Korean Roman Catholic Church. WE CAN Cookies specializes in the making of high quality organic cookies. As a nonprofit organization that uses a labor force of mostly mentally disabled workers, the company faces many challenges that normal companies do not experience. The company had to initially overcome the social prejudice that the handicapped cannot make good cookies. Despite the religious background and social agenda of the company, it started making inroads as a cookie-making business only after its managers, including the nuns who run it began adopting modern management philosophies and practices,

The WE CAN Cookies case illustrates three main marketing-related concepts: One, WE CAN Cookies is a good example of how social enterprises face a broader spectrum of challenges when compared to conventional profit-seeking enterprises. Two. WE CAN Cookies demonstrates that social enterprises need flexibility in formulating their business strategies. Even though WE CAN Cookies is subject to many constraints, as a social enterprise it can also take advantage of new opportunities for obtaining support from the government and from the private sector. Three, WE CAN Cookies shows that these types of operations need to create greater balance in their social and business competencies to ensure the long term viability. Social enterprises are certified by governments with the stated goal of improving the lives and the wellbeing of special interest group. As important as achieving these objectives are, social enterprises also must additionally be able to build their operational capabilities not only in manufacturing but also in functions such as marketing.

Key words: Social enterprise, special interest group, Korean Roman Catholic Church

* This case was developed as part of the ProSPER.Net Project on "Social Business and Social Entrepreneurship Education" sponsored by Asian Institute of Technogy and the United Nations University Institute of Advanced Studies. The author thanks the able research assistance of Cheongyeol Lee and Junyong Kim. Yonsei University in the preparation of this case.

** Professor of Marketing Yonsei School of Business(drchang @ yonsei.ac.kr). corresponding author

*** PhD and Researcher Brand and Business Research Center Yonsei School of Business 


\section{I. "Yes we can!"}

Despite sounding only like the now-famous campaign slogan from Barack Obama's successful U.S. presidential bid in 2008 "Yes we can" is actually the basis for the name of one of the most inspiring social enterprises in Korea. WE CAN Cookies is a company that employs mentally disabled workers and specializes in the manufacturing and the marketing of organic cookies.

The feel-good story of WE CAN Cookies ironically begins with a very sad one. The predecessor of the company was "The House of Aeduk" which means the "The House of Charity," a facility and program operated by the St. Paul de Chartres Nunnery in Korea to help the disabled. The main specialization of "The House of Aeduk" was hiring and training mentally disabled workers to bake cookies.

In 2001, the outfit suddenly faced a crisis when the price of flour skyrocketed. After much deliberation the Nunnery decide to shut down the program. The CEO of WE CAN Cookies, Sister Jin Won Jo recalls the sadness that the closure created (Ministry of Labor, 2010):

While I looked around the empty work area, I would meet workers in front of the locked gates. anxiously waiting for production to restart. I can still clearly remember Eui-Ho, who came every day to see whether the locked gates were open. The disabled people's desire to work and their hopes for a place to work stopped me in my tracks. My deep-felt concern for the disabled. led me to plan a job rehabilitation business for the mentally handicapped. These are the people who have the most difficult time finding jobs in Korea, The constraints of their mental abilities make employment difficult, which in turn makes them even more socially isolated. Therefore. I established WE CAN Cookies, in order to provide them with jobs, or to be more exact, to give them hope.

Against all odds in the winter of 2001. WE CAN Cookies opened for business in a red, two-story brick building in the city of Goyang in Gyeonggii province. Now almost a decade later. WE CAN Cookies is recognized as a model of social enterprise in Korea. It currently has on its payroll of 59 employees 38 who are mentally handicapped.

\section{Social Enterprise in Korea}

In Korean society as a whole, societal welfare has been a secondary consideration not only for corporations but also for ordinary citizens. This was because as a fast-growing developing country, companies and consumers alike were more focused on the wellbeing of the enterprise or the individual. However, in recent years, as Korea has entered into the upper ranks of developed economies the welfare of the underprivileged has become a more salient societal issue that is 
shared by the government, corporations and the Korean people.

Against this backdrop it is easy to understand why social enterprise in Korea is a relatively new concept when compared to other countries. No doubt the awareness and importance of social enterprise grew after Mohammad Yunus, the founder of Grameen Bank won the Nobel Prize for Peace in 2006. Moreover, South Korea had 10 years of governance by pro-labor and liberal minded presidents and administration. The country also witnessed the massive layoffs and the hardship endured by low-income segments of its society following the financial crisis of the late 1990s. At first the government started up public projects to supply more jobs only to learn that this was not a long-term solution.

These movements culminated in the enactment of the Social Enterprise Promotion Act in July 2007 where the Ministry of Labor set the standards for the certification of social enterprises in Korea. In the first year fifty-four companies including WE CAN Cookies were certified as social enterprises. Those chosen were entitled to receive for a limited time tax breaks, labor cost subsidies, and free management consulting services.

\section{Social Philosophy at WE CAN}

The mentally handicapped workers at WE
CAN Cookies are fully involved in the whole process of baking the cookies made at the company - from the kneading of the dough all the way to the packaging. Moreover, even the non-disabled employees at the company function as rehabilitation and social welfare workers. All of the workers are addressed as "friends." This shows the social cause focus of the company. Sister Maria (Soo Kyung Loe) explains (Woman's Magazine, 2010):

We are not in business just to sell more cookies. We sell cookies to provide a good life for our friends.

Working at WE CAN instills an immense sense of pride and responsibility for their mentally handicapped employees. They will monitor stores during the weekend and report back to management about stores that stock their products as well as those that do not. They will also provide feedback about customers' response to the cookies and areas of improvement.

At WE CAN Cookies, rehabilitation programs are carried out along with the cookie making. A 'therapeutic community' program originally created to cure drug addicts in the United States was adjusted to fit the mentally handicapped. Through this program, WE CAN Cookies elicits voluntary participation from the handicapped to instill confidence and teaches social skills and norms. They are also given classes about "Sex Education" and "Sand Therapy."

Among the many programs offered, the workers' 
favorite program is the morning meeting that begins with the greeting of "Hello, We Can." They prepare the contents to present for this program in advance and in doing so, learn to write, speak and express their feelings. The most important thing is that they experience what it is like to raise their hands and speak in front of a group.

There are workers at WE CAN Cookies that have now been working for close to ten years. Their experience at WE CAN Cookies has helped them to assimilate into society as CEO Jo explains (Ministry of Labor, 2010) :

There was a friend named Jin-Ho, who suffered from autism. At first, he didn't reply or express himself, but now he is the first to raise his hand and speak out. Ten years of baking cookies and hanging out with his colleagues at WE CAN Cookies turned him into a much brighter person. One some days going back home from work, he even buys bread. Now, some people might wonder what the big deal is. but for the mentally handicapped, it is a great deal. In July, 2009. there was a national dance competition for the handicapped, where four of our friends entered. Mothers of other mentally handicapped entrants asked them where they were from, and they proudly answered that they were from WE CAN Cookies. Their bright and confident attitude surprised them. I am proud of the friends that are able to talk in front of other people, usher guests from outside, and tell the people around them about the work they do with confidence. The fact that WE CAN Cookies nurtures a sense of dignity and self-esteem in the workers brings me incredible joy.

\section{Business Philosophy at WE CAN Cookies}

The first year of operations at WE CAN Cookies resulted only in net sales of 69 million Korean Won (about $\$ 55,000$ USD). This was much lower than the costs incurred at the company that included wages paid to the disabled workers as well as raw materials such as flour and butter. The situation was made worse due to the lack of technology and capital. As a result, it was hard to make high quality cookies that the consumers would accept.

Despite these initial production setbacks, WE CAN Cookies was able to overcome them and still bake good cookies. However, once the supply problems were solved they discovered a new set of challenges - a lack of demand. Consumers were not willing to buy good-tasting cookies when they discovered that they had been made by the handicapped and on the rare occasions when they bought they did so only out of sympathy. CEO Jo sometimes found herself helplessly wandering around various types of markets acting like a salesman pushing her cookies. Not surprisingly, this type of consumer apathy resulted in lack of distribution channels and soaring costs from the unsold inventory.

Through this experience CEO Sister Jo realized that the only way to survive in this cold competitive market was to produce and market the best possible cookies. She had a strong 
conviction that delicious cookies made with high quality ingredients would not be dismissed simply because they were made by the handicapped. CEO Jo also decided not to emphasize the employees in the advertising of the product. This was not meant to hide that fact but rather to make sure that these cookies were not being forcibly pushed onto the consumers for nonproduct reasons. Sister Jo also began attending a night-time MBA program to learn how to run a company.

While the "best possible cookie" is of course open to subjective interpretation, CEO Jo relied on the timely advice given by the founder of one of the top pastry shops in Korea, Wien that it meant using the best local ingredients, especially flour made from $100 \%$ local wheat. There was a wellness trend blowing in the country and Koreans trusted local wheat to be the best tasting as well as the healthiest ingredient. In keeping with the high quality and domestic ingredients strategy, the company also decided to use eggs, peanuts, black sesame, and butter that were domestic as well as organic. Moreover, no preservatives, coloring, artificial ingredients or powders are used.

The major downside of the "domestic ingredients" only strategy for WE CAN Cookies was that their costs would be much more expensive than for imported materials. For example, when domestic walnuts were 70,000 KRW per kilogram, Canadian walnuts were at priced at one tenth the price at $7,000 \mathrm{KRW}$. The temptation to use lower quality but cheaper ingredients was obviously great but it turns out that WE CAN Cookies was better off to stick to its principles as CEO Jo recounts:

When I thought about the workers who were proud of the handmade cookies baked from domestic ingredients, and our customers who believed in WE CAN Cookies, I could not give in to those temptations. In May 2005, we had to stop our operations for a while because we couldn't get access to domestic flour. At the time we were seriously mulling over whether we should continue to use good ingredients in spite of the hardships. There was criticism that a profit was required in order to continue employing the handicapped. In the end, we did not give up our beliefs in baking 'honest cookies: As a result. that decision gave us the reputation of being a healthy cookie. In 2008 the well-being trend settled in and our product was able to increase market share. In hindsight, the reason WE CAN was able to come this far was because everyone here had strong beliefs in making honest and healthy cookies.

'Honesty' is a fundamental belief that WE CAN Cookies cannot give up. Using the highest quality ingredients is only one part of the whole story. During the cookie making process, sanitary conditions are strictly managed. After the morning meetings, the workers get out their work clothes from the sterilizer and put on their hats and masks. Then the workers use vacuums to get rid of any dust and pass through an air shower. After using air towels and hand 
sterilizers they finally enter the work area. When the cookies are done they are inspected by hand and later pass through a metal detector to check for tiny iron particles. As a direct result of such efforts, WE CAN was certified with the ISO22000 for food safety management in 2008 (Economic Review, 2010).

In 2001, WE CAN Cookies started with modest sales of only 69 million KRW but their turnover has steadily increased over the years. Last year, WE CAN Cookies reported sales of 1.2 billion KRW (about $\$ 1$ million) clearly demonstrating a remarkable progress in less than 10 years of operation. Even with increasing sales, however, it was only after 2007 that it began showing a profit. Not by coincidence, it was one year after being certified as a social enterprise. There were mainly three reasons for the turnaround.

First, the help WE CAN Cookies received from marketing and baking experts after they were certified as a social enterprise enabled the company to be more professionally managed. With the support from the ministry of labor, various promotional materials were made and distributed. WE CAN Cookies was able to set up a systematic marketing strategy and conduct promotions through the media.

The Melamine scandal in 2008 was another reason. The scandal raised demand for safer food and the number of people looking for healthy and safe WE CAN cookies increased dramatically. Because Korea is a close-knit society, the word- of-mouth travels very fast among family, friends, and nowadays via social media. The "word" on WE CAN was that they had great tasting and safe cookies. Of course it doesn't hurt that there is also a good cause behind the operation but people do not cite this as the major reason for them to buy these cookies.

If one types in "WE CAN cookies" in some Internet search engine in Korea such Daum or Naver, the numerous hits will always include positive blogs about consumers' experience with this brand. The company also firmly believes that these positive responses were a direct result of them enduring times of hardship without giving in to temptations to break their promise to their customers.

Finally, the support from social enterprise networks and volunteer work institutions were a great help. Since the WE CAN Cookies staff formerly consisted only of social and rehabilitation workers, the pro bono consulting on production, marketing, accounting, and all other areas of management were extremely helpful in getting the company off the ground.

WE CAN Cookies also practices ethical management and formed a task force team at the WE CAN Center to spearhead that movement within the organization. The task force developed an education program and a code of ethics that all employees must follow. The program and code of ethics takes into consideration the special nature of the company and formulates ethics pertaining to the responsibilities and ob- 
ligations that employees bear to customers as a social enterprise as well as to the disabled workers at WE CAN as a rehabilitation center for the disabled. The ethics management committee is consulted by both WE CAN's operating and labor-cooperating committees.

\section{Meshing Social and Business Philosophies and Practices at WE CAN Cookies}

Many of the challenges faced by WE CAN Cookies are shared by other social enterprises certified by the Ministry of Labor in Korea. As such their remedies may be similar also. One commonly shared difficulty is a general lack of awareness by the public about the concept of social enterprises and the negative perception of their products. In the specific case of WE CAN COOKIES it was overcoming the societal prejudice that good cookies cannot be made by mentally disabled people. This is where activities that educate the public to change their way of thinking can be extremely beneficial. One such venue was "Chef Experience for Tots" co-sponsored by WE CAN COOKIES and the Korean Post Office. The special event had children learning from WE CAN COOKIES employees on how to bake cookies (see Figure below). Not only did the children have a great time but more importantly they saw firsthand how disabled people are quite normal - a mindset they can carry on to their adulthood and pass on to other people.

Many of the cited problems suffered by social enterprises are related ultimately to the sufficiency of the support for social enterprises. Since the support such as labor costs subsidies are for a limited time, given that profit seeking must be balanced with socially oriented corporate mandates, the support may prove to be inadequate until the social enterprises are fully established as self-sufficient entities.

WE CAN COOKIES is a social enterprise that hires mentally handicapped people and returns the profits back to them. A social enterprise must be able to fulfill its economic and social objectives at the same time. It is a difficult situation where two extreme concepts exist in a single organization. However, in order to differentiate these enterprises from regular companies, a greater weight has to be placed on achieving social objectives. WE CAN COOKIES not only provides stable employment to the mentally handicapped, but also operates various programs to bring them back into society. Nevertheless, the hard reality of having to maintain a consistent profit has forced the CEO and managers at WE CAN COOKIES to consider making compromises. In the end although it was difficult WE CAN COOKIES decided not to let go of their various rehabilitation programs. It is a decision that the organization and the "friends" at WE CAN 
COOKIES are happy about. However, the question remains whether the social versus business objectives "balancing act" can be constantly tipped towards the former direction.

Being the first generation of social enterprises there are other hurdles that must be surmounted. Some of the biggest ones for WE CAN COOKIES are securing stable distribution channels and obtaining expertise on new product and market development. Many of the certified social enterprises specialize in one product line. In terms of distribution, this creates the problem of lack of economies of scale in distribution, new product and market development. Part of the solution may lie in collaborating with other social enterprises. Already WE CAN Cookies has teamed up with another social enterprise called Bari's Dream that focuses on eco-friendly traditional food manufactured by displaced Korean ex-pats. The co-marketing project has lead to the creation of a "Chungguk Chang" (Soya) based cookie that will be marketed in both companies' channels. As more and more social enterprises are certified, these types of mutually beneficial alliances that can create value chain cost efficiency will be vital in ensuring the collective sustainability of these nascent businesses.

Part of the government support was also providing tax breaks for businesses that directly work with the certified social enterprises. Many critics have pointed out that the narrow definition and eligibility of these "connected businesses" have stunted the growth of social enterprises. Many of these companies including WE CAN Cookies have originated from nonbusiness backgrounds and therefore require diverse management skills in areas such as marketing, finance, accounting and human resource development. Even though the government has offered some basic training in these areas that help needs to be more specialized to the individual social enterprises. Simply put the consulting has to from companies in a similar line of business. As we have seen WE CAN benefited immensely from the ad hoc and pro bono advice of companies in the pastry industry. This practice has to be systematized and more importantly, greater incentives have to be provided when such assistance is given. If WE CAN is successful in attracting managerial support from regular businesses, then aside from the obvious benefits what are the risks involved and how do they lessen them?

The gap in productivity between the mentally handicapped and the non-handicapped is another problem (the productivity ratio of the latter to the former is 8 to 1 ). The former CEO, Sister Agatha (Hyang Sook Won), knew that it would be cost effective to adopt factory automation techniques to save costs. That however would defeat the underlying social objective to hire more disabled employees. Currently the support from the ministry of labor has ended and thus the pressure to increase productivity has intensified. To make this matter worse, many longtime and rehabilitated work- 
ers at WE CAN are transferred for employment at regular companies. This must be done not only for their growth but also in order to create new opportunities at WE CAN for the handicapped where applications outnumber the number of jobs by more than two to one. The influx of new workers increases the need to train them and bring up their productivity.

Related to the productivity problem is that motivating the mentally disabled to increase their output is very difficult. Whereas with regular workers, economic incentives can be effective, that is not the case with WE CAN's handicapped employees. Unconventional human resource management practices therefore have to be adopted that ensures positive results while at the same time respects the special vulnerabilities of these disadvantaged workers.

\section{Business and Marketing Takeaways from WE CAN Cookies}

First and foremost, the case illustrates that we need to understand the essentially different nature of social enterprises. WE CAN Cookies was founded by the Roman Catholic Church in Korea. As such, the core mission and principles of the company are in stark contrast to those of conventional firms where there is a more focused emphasis on business-related agenda and key performance indices. Moreover, WE CAN Cookies specializes in employing a special interest group -the mentally disabled. While this may be laudable as a social objective, it puts an extra burden on WE CAN Cookies on its achieving of its business objectives such as increasing and maintaining high quality, improving manufacturing productivity and lowering costs. These employees who require a different and costlier kind of training often leave the company to pursue employment at regular companies in order to enhance their growth as members of society at large. WE CAN Cookies encourages this because assimilating their workers into the regular workforce is part of their social agenda even though it directly hurts them from an economic standpoint. Also as a social enterprise, WE CAN Cookies must reinvest its profits on its designated special interest group. This further hampers the sustainability of the social enterprise.

The second learning from WE CAN Cookies is that its model for success as a social enterprise stems from a broad spectrum of factors. WE CAN Cookies was one of the earliest social enterprises in Korea founded in 2001. This was 6 years before the Korean government began the certification program. It enjoyed therefore undivided attention to an important social cause for a special interest group - the mentally disabled. From a consumer behavior standpoint it appealed to people's altruistic sensibilities to help others that they perceive to be in need. A 
complementary element is that they could show other people that they are contributing to such worthy social causes as can be seen by owners of the Prius in the U.S (Griskevicius et al, 2007). Such ostentatious and yet socially-conscious behavior is reflected when consumers of WE CAN Cookies give their friends and families this cause-worthy brand as gifts. In a collectivistic culture like Korea, strong social influence such as via offline and online word of mouth can lead other people to follow in their positive example. Another important factor that contributed to WE CAN's success was the proactive acceptance by its managers, including the nuns who run the company that it had to be operated more professionally as a business. The first CEO, Sister Agatha, was called a CEO and she even enrolled in an MBA Program to learn modern management practices. Even though balancing a social and a business agenda can be a tough juggling act, WE CAN Cookies demonstrates that to some degree it can be done. Finally, we can consider social responsibility and corporate image dimensions (Kim and Kim. 2010) and especially reputation-management. WE CAN Cookies has enjoyed the benefit of getting the backing of the Roman Catholic Church of Korea. The reputation of the Roman Catholic Church is the highest among all major religions in Korea (The Christian Ethics Movement, 2010). It has helped the company to establish trust in a country where there is often suspicion about the quality of the food. This mis- trust has been exacerbated by scandals such as the Melamine contamination of food. This "halo effect," along with WE CAN Cookies use of only domestic organic ingredients such as wheat. and its ISO 22000 accreditation have led to a high consumer trust in the brand.

The last takeaway is that WE CAN Cookies, even despite all their success, still faces many obstacles in becoming a sustainable social and business enterprise. It is true that a supportive governmental policy and privileges have had a positive effect on social enterprises and their special interest groups. However, the case shows that social enterprises including WE CAN Cookies may still need more support in order for them to maintain their success. A major question is whether the originally stipulated time period of three years is sufficient for these companies to become self-sufficient. While some companies that are similar to regular business enterprises may realize such sustainability during that time, some other companies like WE CAN Cookies, given their social mission of using lower productivity workers, the time needed to become self-sufficient may be much longer. The same kind of argument can be made about the financial support provided to social enterprises - for some companies the higher costs of their operations such as in raw materials, cost of training, and lack of channels may require more subsidies. Some other considerations can be the qualitative support that social enterprises need such as specialized managerial knowhow like opening. 
promoting, and managing new market channels. In the case of WE CAN Cookies, the specialty confectionary industry is very competitive and for them to maintain or to upgrade their product quality and brand image may call for continued support from outside experts such as in manufacturing and marketing.

Future discussion about WE CAN Cookies should revolve around what creative solutions and diversified performance criteria have to be devised so that they can better synergize their social and business mandates.

〈Received April 30. 2012〉 〈Revised November 27. 2012〉 〈Accepted December 1. 2012〉

\section{References:}

Economic Review, "Experimental Operation of Social Business Model: Hope over Profits," http://er.asiae.co.kr/erview.htm?idxno $=20$ 10102114351775266.
Griskevicius, Vladas, Joshua M. Tybur, Jill M. Sundie, Robert B. Cialdini, Geoffrey F. Miller, and Douglas T. Kenrick, "Blatant Benevolence and Conspicuous Consumption: When Romantic Motives Elicit Strategic Costly Signals". Journal of Personality and Social Psychology, 2007, Vol. 93, No. 1

Kim. Seong Jin and Jong Keun Kim, "The Effect of Corporate Social Responsibility on Corporate Image: The Role of Spillover Effect and Negativity Effect based on CSR dimensions," Asian Journal of Marketing, Vol.11, No.4, pp. 49-67.

Korean Church Social Trust Survey, The Christian Ethics Movement,2010.12.15

Ministry of Labor, "The stories of social enterprises in our neighborhood," July 7. 2010. Woman's Magazine , "Welcome to WE CAN!" April 5, 2010 